\title{
A ANDRÔMACA DE EURÍPIDES COMO FONTE DE AS TROIANAS DE SÊNECA
}

\author{
ANA MARIA CÉSAR POMPEU* \\ Universidade Federal do Ceará
}

\begin{abstract}
RESUMO: Observa-se uma considerável influência de Andrômaca de Euripides em As Troianas de Sêneca, especificamente no segundo episódio, cuja figura central é Andrômaca, e na segunda cena do primeiro episódio, que corresponde ao debate de Agamêmnon e Pirro sobre a morte de Polixena.
\end{abstract}

PALAVRAS-CHAVE: teatro; Sêneca; Andrômaca; As troianas.

\section{Introdução}

O teatro de Sêneca apresenta, nas suas dez peças trágicas, nove com temas gregos, considerando-se ainda que a única pretexta é tida como espúria. Discute-se muito acerca do objetivo do autor ao imitar as tragédias helênicas; sabe-se, no entanto, que tais peças não são sua única fonte, pois há, em seu teatro, influência dessas obras e das dos autores latinos da época helenística. E Sêneca não se serve somente do gênero trágico para a elaboração dos textos, mas busca inspiração na épica e na poesia lírica (Herrmann, 1924, p. 326).

Ora, é indiscutível que suas principais fontes foram os grandes tragediógrafos gregos, e que, dentre eles, a sua predileção está em Eurípides. As troianas de Sêneca, que será estudada neste trabalho, tem como principais fontes duas obras desse autor grego: As troianas e Hécuba. O drama senequiano reúne os temas dessas duas peças: a morte de Políxena em Hécuba, e a de Astíanax em As troianas.

Ocorre, porém, que nas duas peças de Eurípides a figura central é Hécuba, mãe e avó respectivamente de Políxena e Astíanax. Andrômaca, mãe deste último, desempenha um papel menor somente em As troianas, que trata da morte do pequeno príncipe troiano. Em Sêneca, entretanto, essa personagem vem com maior força e divide, com a velha rainha troiana, grande parte de toda a peça, embora Hécuba não deixe de ser a figura central, por representar a própria Tróia destruída. 
O segundo episódio de As troianas de Sêneca tem Andrômaca como figura central. Essa parte corresponde a pouco mais de um terço da totalidade da peça, e apresenta o sofrimento da mãe ao ser privada do único consolo que lhe resta, o seu filho Astíanax, depois de ter presenciado a morte do esposo querido, Heitor, pela mãos do grande herói grego, Aquiles, enquanto ainda durava a guerra, e de ter visto Tróia ser destruída pelo inimigo vencedor.

Ora, se Sêneca se serviu de duas peças de Eurípides para traçar o perfil de Hécuba, faltaria uma obra do mesmo trágico que retratasse mais especificamente Andrômaca. Mas não se explorou muito Andrômaca como fonte de As troianas de Sêneca, pelo menos não no mesmo nível das outras duas peças de Eurípides já citadas. Há uma razão muito forte para isso: é que As troianas e Hécuba tratam do mesmo assunto da peça senequiana, ou seja, das mulheres troianas logo após a destruição de seu país pelos gregos, ainda nas próprias ruínas de Tróia, e Andrômaca traz, em seu enredo, o destino de Andrômaca após a chegada dos gregos à Grécia. E assim ela está no solo da Ftia, para onde foi levada por Pirro ou Neoptólemo, ${ }^{1}$ filho de Aquiles, a quem coube por sorte na condição de cativa.

O que essa peça apresenta é o momento em que Pirro está ausente do país, tentando retratar-se de um insulto feito a Apolo, deus de Delfos, e Andrômaca corre perigo de vida juntamente com seu filho. Sendo concubina de Pirro, deu-lhe um filho, enquanto a esposa legítima, Hermíone, filha de Menelau e Helena, era estéril. Esta, acusando a troiana de torná-la assim, através de filtros mágicos, quer se livrar da concorrente e da criança, e para isso pede a ajuda de seu pai, Menelau. Então, Andrômaca envia o filho para longe do palácio e se refugia no altar da deusa Tétis, onde não podia ser molestada, por ser um lugar sagrado.

Em As troianas de Sêneca, no primeiro episódio, a segunda cena apresenta a discussão entre Pirro e Agamêmnon sobre o sacrifício de Políxena no túmulo de Aquiles: enquanto Pirro exige o sacrifício como honras devidas a seu falecido pai, Agamêmnon, chefe dos exércitos gregos, não quer permitir esse crime. Embora o tema dessa cena não trate de Andrômaca, essa passagem é apontada como muito semelhante a de Andrômaca, em que Peleu, velho pai de Aquiles e avô de Pirro, e Menelau, irmão de Agamêmnon, discutem sobre a morte de Andrômaca e de seu filho: Menelau quer matá-la por prejudicar sua filha Hermíone, e Peleu a defende.

As semelhanças dessas passagens são, além da escolha dos personagens das mesmas famílias rivalizando pela vida de uma cativa troiana - numa peça, Políxena, na outra, Andrômaca -, os argumentos retóricos e sofísticos utilizados em ambas as discussões. 
Vê-se então que, mesmo tendo enredos diferentes, as semelhanças entre as duas peças, As troianas de Sêneca e Andrômaca de Eurípides, são muitas. São tais semelhanças que serão tratadas neste estudo, e que podem ser agrupadas em três níveis: tema, ação e personagem. ${ }^{2}$

\section{As fontes no teatro de Sêneca}

León Herrmann (Herrmann, 1924, p. 233) propõe uma questão: o teatro de Sêneca "é um teatro de imitação ou é uma tentativa para criar um gênero original?" E, nessa indagação, ele apresenta as diversas teorias sobre o objetivo e a natureza das tragédias de Sêneca, que são assim enumerados: objetivo retórico, de oposição política, de oposição religiosa, de filosofia religiosa, pedagógico, moral, paródia de críticas literárias, e, finalmente, objetivos múltiplos mas principalmente literários (id., ib.).

A seguir, Herrmann analisa como são escolhidos os temas nas tragédias de Sêneca, distribuindo as peças de acordo com as lendas (id., ib.):

1. lendas do ciclo de Argos: Tieste; Agamêmnon;

2. lendas do ciclo troiano: As troianas;

3. lendas do ciclo tebano: Édipo; As fenícias;

4. lendas de Hécules: Hércules furioso; Hércules sobre o Eta;

5. lenda dos Argonautas: Medéia;

6. lenda de Teseu: Fedra.

Conclui, então, que Sêneca prefere as lendas mais célebres, exploradas pelos trágicos gregos, abandonando as menos importantes e também as que substituem a tradição por invenções romanescas. Nota que o trágico latino renuncia aos assuntos de interesse muito local, não tratando, desse modo, do Íon, das Suplicantes, dos Heráclidas, de Édipo em Colono, das Eumênides. Nota ainda que uma só de suas tragédias, Fedra, se passa na Ática; as outras são tebanas, argivas, coríntias ou troianas, e seu caráter nacional desaparece. Observa ainda que Sêneca evita as tragédias muito simples ou muito comportadas, como o Prometeu acorrentado ou Filoctete, e que escolhe modelos cujo assunto tenha uma intriga menos rudimentar. E que se desvia dos assuntos em que o patético é calmo e moderado, como em Alceste, pois seu gosto se volta quase sempre para as ações violentas, os "belos crimes" (Tiestes, Medéia, Agamê- 
mnon) e também para os casos patológicos (Hércules furioso, Fedra). E, ainda, que ele prefere assuntos que se prestem ao desenvolvimento psicológico e permitam o estudo detalhado de uma paixão, e exemplifica: em Tiestes há o estudo do ódio, e em Fedra, o estudo do amor. Então sintetiza sua teoria, afirmando que, na adoção de certos temas e na exclusão de outros, mostram-se os gostos pessoais de Sêneca pelos assuntos gerais, complexos, movimentados e violentos, e principalmente por temas que permitissem um estudo psicológico aprofundado (Herrmann, 1924, p. 252-3).

Herrmann afirma que é unicamente por razões literárias que Sêneca se volta para temas gregos, pois o tragediógrafo latino escolhe temas rebatidos, conhecidos por seus contemporâneos, não somente nos originais, mas ainda através de múltiplas cópias ou adaptações tanto épicas ou líricas quanto dramáticas:

É que ele se serve destes temas como de um ponto de partida cômodo e incontestável e que lhe permite, precisamente, manifestar a fecundidade de seu gênio e sua virtuosidade poética (id., ib., p. 254).

Florence Dupont, entretanto, esclarece que os poetas latinos, que escreviam suas peças a partir de tragédias gregas, deviam torná-las aceitáveis, inteligíveis para seu público (Dupont, 1988, p. 46). Explica que a cultura grega é uma "cultura de mitos", o que não é a cultura romana, pois para os romanos a mitologia grega era apenas uma sucessão de relatos fabulosos que não lhes pertenciam, embora eles estabelecessem equivalências entre seus deuses e os dos gregos. E acrescenta que os mitos na Grécia faziam parte da realidade existente, e que a cidade encontrava lugar para eles nas celebrações solenes da memória coletiva. E, ao contrário dos gregos, os romanos não se interrogam sobre o sentido dos mitos gregos, porque eles não têm necessidade de encontrar um lugar do crime mítico na memória cultural, pois era suficiente, para eles, dar-lhe um nome romano e o situar fora da humanidade (id., ib.). Tanto era assim, afirma Dupont, que eles não modificavam os nomes das personagens e dos lugares, que continuavam gregos. O crime trágico é então assimilado a uma noção romana, o scelus nefas, em que o culpado é automaticamente expulso da humanidade: "o crime trágico, na tragédia romana, é cometido por um grego que se transforma em monstro" (id., ib.).

\section{As troianas e suas fontes}

As fontes possíveis de As troianas de Sêneca são muito numerosas, porque a morte de Políxena e de Astíanax são dois temas sempre tratados isoladamente. 
Eurípides consagrou à morte de Políxena a primeira parte de sua Hécuba, e à morte de Astíanax o fim de As troianas. Sófocles teria tratado da morte de Astíanax nas Aichmalotídes, e de Políxena em Políxena. Houve também entre as obras latinas a Andrômaca aichmalotís e a Hécuba de Ênio, vindas uma da Andrômaca de Eurípides e a outra de sua Hécuba; houve ainda Troades ou Astianax e Hécuba de Ácio. Só há fragmentos dessas tragédias latinas e desses dramas de Sófocles (Herrmann, 1924, p. 267).

As duas principais fontes de As troianas de Sêneca são, indiscutivelmente, As troianas e Hécuba de Eurípides, que tratam exatamente do mesmo episódio das cativas troianas nas ruínas de Tróia e da morte de Astíanax e de Políxena respectivamente. Mas notam-se muitas inovações na obra de Sêneca.

Em As troianas de Sêneca, em vez de Taltíbio vir arrancar seu filho à Andrômaca, como em Eurípides (As troianas v. 704s), supõe-se que a mãe, advertida em sonho pelo falecido esposo, Heitor, e aconselhada por um velho, tem a idéia e o tempo de esconder a criança no túmulo de Heitor, de onde, por artimanha, Ulisses virá retirá-lo. A idéia viria, de acordo com certos eruditos, de Ácio e, através dele, das Cativas de Sófocles. Mas parece que em Ácio era um escravo que encontrava a criança escondida em um bosque e a enviava a Ulisses. A idéia do túmulo de Heitor pertence, conclui Herrmann, a Sêneca (Herrmann, 1924, p. 267).

As inovações na tragédia não são raras, pois todos os tragediógrafos fazem adaptações de acordo com a necessidade dramática. Aristóteles, na Poética, é claro ao dizer:

Não é necessário seguir à risca os mitos tradicionais donde são extraídas as nossas tragédias; pois seria ridícula fidelidade tal, quando é certo que ainda que as coisas conhecidas são conhecidas de poucos, e contudo agradam elas a todos igualmente. Daqui claramente se segue que o poeta deve ser mais fabulador que versificador; porque ele é poeta pela imitação e porque imita ações (1451 b 23-29).

No que se refere a Políxena, também há inovações: em Eurípides, Ulisses vem simplesmente anunciar que os gregos decidiram imolar a virgem aos manes de Aquiles, porque ele o reivindicou (Hécuba, v. 276s); já Sêneca imaginou outra coisa (As troianas, v. 366s): que Políxena deveria ser vestida como uma virgem grega no dia do seu casamento, e que era preciso enganar as troianas fazendo-as crer em um casamento real em que Helena seria a "pronuba" (Herrmann, 1924, p. 268-9). Parece que, nessa passagem, a influência predominante foi de Ifigênia em Áulis, também 
de Eurípides, onde a filha de Agamêmnon é sacrificada à deusa Ártemis, para que os ventos se tornem favoráveis à navegação, e a frota grega possa partir para guerrear contra Tróia. E o rei Agamêmnon faz Clitemnestra, sua esposa, enviar a filha para Áulis, fazendo com que ambas, mãe e filha, creiam que Ifigênia se casará com Aquiles. Não se pode deixar de mencionar que o sacrifício de Políxena também é motivado pelo apaziguamento dos ventos, mas agora para que a frota grega volte à Grécia.

Com relação à ação, o prólogo dito por Hécuba em As troianas de Sêneca não é semelhante nem ao dito por Polidoro em Hécuba, nem ao dito por Netuno em As troianas, ambas as peças de Eurípides, ainda que contenha reminiscências dos dois, pois é dito por uma personagem, Hécuba, que não profetiza os acontecimentos subseqüentes, apenas faz alusão a seu poder de premonição quando estava grávida de Páris (As troianas, v. 34s), mas ela só se lamenta. Não se poderia apelar para o Astíanax de Ácio como fonte deste prólogo, que se aproxima antes do párodo de Hécuba de Eurípides (Herrmann, 1924, p. 269).

A cena de Taltíbio, no primeiro episódio (As troianas, v. 163-202) seria, segundo alguns, inspirada em Hécuba de Eurípides, enquanto outros admitem a imitação de Políxena de Sófocles. Mas parece evidente que a fonte desta cena é Hécuba v. 130s, mesmo que em Sêneca haja a substituição do coro grego por um mensageiro. A segunda cena desse mesmo episódio, que é a da querela dos reis (As troianas, v. 203-352), é estranha a Eurípides. Herrmann fala da influência de Hécuba v. 260s e v. 278, e a de Andrômaca v. 575s, da discussão entre Peleu e Menelau, que recordaria esta de Agamêmnon e Pirro, e afirma que o que parece é que houve uma contaminatio: na cena tomada a Homero, Sêneca modificaria o papel de Agamêmnon e o tomaria por empréstimo de Hécuba de Eurípides; ele substitui Aquiles por Pirro e coloca, depois da altercação, a intervenção de Calcas, que a precede na Ilíada (Herrmann, 1924, p. 269-70).

O segundo episódio comporta, de início, a cena em que Andrômaca relata o sonho que teve (As troianas v. 409-523) e decide, a conselho de um velho, esconder Astíanax. Este sonho recorda antes uma visão da Eneida, II, 170s.

Quanto à segunda parte da cena, Herrmann diz que a idéia de esconder a criança no túmulo é uma invenção de Sêneca (Herrmann, 1924, p. 271). A chamada grande cena do túmulo entre Ulisses e Andrômaca (As troianas, v. 524-813) suscitou as maiores discussões sobre suas fontes: a maioria dos críticos, explica Herrmann, aponta Astíanax de Ácio, e também se aponta a influência de Hécuba v. 561, onde uma mensagem é também endereçada a Príamo morto, por intermédio 
de Políxena (Herrmann, 1924, p. 272). Ainda se crê na influência de Andrômaca de Eurípides e da Eneida 3. v. 489. Mas o conjunto da cena parece pertencer a Sêneca que ali amalgamou habilmente toda sorte de reminiscências.

O terceiro episódio se voltará em parte a Hécuba em parte a As troianas de Eurípides. $\mathrm{O}$ papel de Helena é original, mesmo se o estratagema das falsas núpcias vem de Ifigênia em Áulis v. 98. As invectivas de Andrômaca e Helena se aproximam do fragmento 7 de Astíanax de Ácio, e a defesa de Helena vem certamente de sua cena com Menelau em As troianas de Eurípides. É também de As troianas v. 271s que vêm os versos sobre a partilha das cativas. As maldições finais de Hécuba contra a frota grega não são tomadas somente das de Cassandra em As troianas de Eurípides, mas das palavras da própria Hécuba nos versos 382s de Hécuba (Herrmann, 1924, p. 272). Quanto ao arrebatamento de Políxena por Pirro, ele porta a marca de Sêneca. O êxodo, Herrmann o considera uma contaminatio de Hécuba e As troianas de Eurípides.

As fontes das personagens (Herrmann, 1924, p. 273) são às vezes difíceis de determinar: Pirro, por exemplo, é estranho a Eurípides, desprovido da generosidade do Aquiles homérico e da do Neoptólemo de Sófocles; o mesmo ocorre em relação à personagem secundária de Calcas.

A Hécuba de Sêneca tem um caráter às vezes mais simpático e mais heróico que o da Hécuba de As troianas de Eurípides, menos emocionada e menos dolorosa.

O Ulisses de Sêneca não tem grande coisa em comum com o que nos apresenta Sófocles no seu Ájax, que é moderado, sábio e generoso; seria mais próximo do Ulisses pérfido e cheio de artimanhas de Filoctete ou do de Reso, que do herói do Ciclope ou de Helena porque é mais duro que este último. Esta acentuação do papel talvez venha de Astíanax de Ácio.

A personagem de Helena recorda mais Homero que a criação fantasista de Eurípides (Helena, v. 362s).

O Agamêmnon de Ifigênia em Áulis, pai frágil e doloroso, aproxima-se, em certa medida, do herói de Sêneca, mas deve-se procurar a fonte principal em Hécuba de Eurípides, onde ele é um rei piedoso que defende sua cativa oprimida.

Políxena, que desempenha um papel mudo, menos criativo do que na Hécuba de Eurípides, tem de Ifigênia o patriotismo e a coragem (Ifigênia em Áulis v. 1368s).

Andrômaca é diferente da de Eurípides: a finalidade do papel distingue a heroína de Sêneca da Andrômaca mais queixosa que aparece na Hécuba de Eurípides.

O papel de Astíanax parece original; Taltíbio tem um papel bem mais reduzido que em Eurípides; o velho é talvez inspirado em Ifigênia em Áulis e na Eneida. 
O párodo vem de As troianas de Eurípides; o primeiro estásimo seria original, salvo por algumas reminiscências de Virgílio ou de As troianas de Eurípides; o segundo estásimo é um amálgama de As troianas e de Hécuba de Eurípides; o terceiro apresenta algumas analogias de detalhes com essas duas obras, mas se distancia no final.

Um outro ponto é que Sêneca faz o prólogo fundir-se com o párodo, em vez de ser pronunciado por um deus, como em As troianas de Eurípides. A ação mais complexa e mais dramática, do fato da fusão de dois temas põe uma dupla questão. Em vez de uma tragédia do destino e da fortuna, nós temos uma peça mais psicológica, que estuda sobretudo a dor maternal em Andrômaca e em Hécuba (Herrmann, 1924, p. 273).

Sêneca não tem método geral e fixo de imitação, tanto procede por contaminatio, como no caso de As troianas, como recorre a um modelo principal, como no caso de Hércules furioso ou de Édipo; tanto se contenta com fontes dramáticas, como junta fontes épicas ou líricas. Sêneca se endereça de preferência aos grandes trágicos gregos, mas não negligencia os latinos arcaicos; sua predileção entre os primeiros é por Eurípides.

\section{Andrômaca: uma fonte principal de Sêneca?}

A Andrômaca de Eurípides é considerada uma obra secundária. Os próprios antigos a julgavam assim, pois, como afirma Albin Lesky, nos fragmentos de uma didascália, que provavelmente remonta a Aristófanes de Bizâncio, a obra já é colocada entre as de segunda categoria (Lesky, 1968, p. 403). Segundo o escólio ao verso 445, Andrômaca não foi representada em Atenas, e ele a coloca na época dos primeiros anos da guerra do Peloponeso. Houve críticos posteriores que pensaram em Argos ou na província dos molossos (id., ib.). Essa suposição deve-se ao fato de que Eurípides teria escrito a peça em homenagem a tal povo, uma vez que o filho de Andrômaca com Pirro, Molosso, viria a ser o fundador da casa real dos molossos. A violenta tendência anti-espartana que se expressa no retrato de Menelau concorda com a composição da peça nos primeiros anos da guerra. Do ponto de vista formal, é notável o lamento de Andrômaca em dísticos elegíacos (v. 103).

Na nota a sua tradução da peça, Louis Méridier afirma que, se a parte de criação que vem de Eurípides na utilização do mito parece considerável, a psicologia mostra uma originalidade não menos ousada que a condução mesma da ação: o autor retirou de seus personagens a grandeza heróica que eles tinham na tradição, 
para mostrar suas fraquezas com um realismo quase cruel. Esse realismo, que corresponde a uma das tendências profundas de Eurípides, não é em nenhuma parte mais sensível do que nesta peça. A figura de Andrômaca não foi poupada. Nesta mulher irritada, racional, pronta ao sarcasmo e ao insulto, que expõe com tão pouca dignidade suas estranhas complacências para as infidelidades do esposo, quem reconheceria a doce e pura Andrômaca da epopéia homérica, do canto VI da Iliada?

A Andrômaca de Sêneca é a personificação da mulher esposa e mãe (Cardoso, 1976, p. 137). Tróia para ela era Heitor e ele está morto (v. 413). Tudo que lhe resta são as lembranças do esposo, até Astíanax é visto só como o filho de Heitor. E ele é a causa de suas aflições, pois ela só teme, naquele momento, pela sorte do filho (v. 421): a coragem que revela diante das ameaças de Ulisses (v. 583s); a fraqueza diante do relato da morte que o filho sofreria, se os gregos o encontrassem (v. 623); o seu medo constante revelado pelas reações fisiológicas e psicológicas. É a sua condição de mãe e esposa que a torna temerosa, astuciosa, indecisa, patética. A sua ironia vem de toda a amargura da perda do esposo e do filho. É uma personagem plana.

A Andrômaca de Eurípides na peça homônima fala com tristeza e saudade de Heitor, mas parece que ela coloca tal fato no mesmo nível da destruição de Tróia, enquanto a de Sêneca só lamenta Tróia pela perda do esposo querido.

Em alguns pontos as duas Andrômacas se aproximam. Como a de Sêneca, a de Eurípides é arrogante quando dialoga com Hermíone (v. 183/273), audaciosa no diálogo com Menelau (v. 319s), não hesita em pronunciar palavras agressivas, cheias de ódio (v. 445s). Mas o orgulho desaparece quando deve salvar o filho, pede-lhe que suplique pela clemência de Menelau (v. 330-334), como a Andrômaca de Sêneca manda que Astíanax peça a de Ulisses (v. 707s; Cardoso, 1976, p. 139-41). A Andrômaca de Sêneca "é mais instintiva, mais primitiva, mais apaixonada" (Cardoso, 1976, p. 141). A de Eurípides é mais racional: no diálogo dela com Hermíone (v. 183-273), vê-se que, para ela, Heitor não era o esposo perfeito, com o qual a Andrômaca senequiana quer, mesmo que seja através de um sonho, ou através do filho, ter alguma espécie de contato. O que a de Eurípides quer é ressaltar suas próprias virtudes de esposa (v. 226; Cardoso, 1976, p. 141-2).

Algumas cenas do segundo episódio de As troianas de Sêneca fazem lembrar outras da Andrômaca de Eurípides: a cena em que ela oculta Astíanax no túmulo de Heitor para livrá-lo dos inimigos gregos, de qualquer maneira, recorda a outra cena em que ela oculta o filho, para livrá-lo de Hermíone e de Menelau; a artimanha de Ulisses para fazê-la denunciar o esconderijo de Astíanax também faz lembrar a de Menelau para fazê-la sair do altar de Tétis; o pedido dela para que Astíanax implore 
pela clemência de Ulisses se compara ao mesmo pedido seu para que o filho suplique a clemência de Menelau; e, finalmente, a resposta de Ulisses a seu pedido de clemência, que afirma que quanto mais ela se preocupa com o filho, mais ele se preocupa com o futuro de seu próprio filho, Telêmaco; enquanto Menelau responde que deve querer o bem dos seus e não dos bárbaros. Essas respostas se diferenciam no fato de que a de Ulisses em As troianas de Sêneca é mais humana, quando ele afirma que se compadece pela dor de uma mãe, mas que se compadece bem mais pela dor das mães gregas:

UL. Hic ipse, quo nunc contumax perstas, amor consulere paruis liberis Danaos monet.

Post arma tam longinqua, post annos decem minus timerem quos facit Calchas metus, si mihi timerem: bella Telemacho paras (v. 589-93)

UL. O mesmo amor, no qual persistes contumaz, ensina os gregos a velar pelos filhos pequeninos. Depois de guerras tão longas, depois de dez anos, eu temeria menos as ameaças que Calcas faz, se temesse para mim; (mas) tu preparas guerras para Telêmaco; ${ }^{3}$

UL. Alios parentes alloqui in luctu decet:

tibi gratulandum est, misera, quod nato cares, quem mors manebat saeua praecipitem datum e turre, lapsis sola quae muris manet (v. 619-22)

UL. A outras mães é preciso consolar, quando em luto; a ti deve-se felicitar, ó desgraçada, já que estás privada de teu filho a quem se destinava uma morte cruel: atirado da única torre que resta das muralhas derrubadas;

AND. Quid agimus? Animum distrahit geminus timor: hinc natus, illinc coniugis cari cinis (v. 642-3)

AND. Que fazer? Um duplo temor divide minha alma. De um lado meu filho; de outro a cinza do esposo querido;

AND. Submitte manus dominique pedes supplice dextra stratus adora (v. 708-9) 
AND. Abaixa as mãos e, prosternado, com a mão suplicante, adora os pés de teu senhor;

UL. Matris quidem me maeror attonitae mouet, magis Pelasgae me tamen matres mouent, quarum iste magnos crescit in luctus puer (v. 736-8)

UL. É evidente que a mágoa de uma mãe aterrorizada me comove, mas me comovem mais as mães pelasgas para cujo luto este menino cresce.

Na Andrômaca de Eurípides há discursos semelhantes a esses de As troianas de Sêneca:

MEN. Kei mè tód'éklipous'pédon, hód'antì toû soû sómatos sphagésetai.

Taût'oûn logízou, pótera katthaneîn théleis

hè tónd'olésthai sês hamartías hýper, hén eis ém'és te paîd'emèn hamartáneis (v. 314-8)

MEN. Se tu não abandonas este solo, este é que será sacrificado em teu lugar. Tu, daí reflete! Escolhes morrer ou vê-lo pagar com a vida a falta que tu cometes comigo e minha filha;

AND. Oímoi, pikràn klérosin haíresinté moi

biou kathistes kaì lakhoûsá g'athlía

kaì mè lakhoûsa dystykhês kathístamai (v. 384-6)

AND. Ai de mim, como é cruel, o apelo a sorte, a escolha da vida que tu me impões! Miserável, se a sorte me favorece; infeliz, se ela é contrária!;

AND. Líssou, goúnasi despótou khrimpton, ô téknon (v. 529-30)

AND. Suplica-lhe; toca os joelhos do senhor, meu filho;

MEN. Tí me prospitneis, halian pétran

è kûma litaîs òs hiketeúon?

toîs gàr emoîsin gégon'ophelía,

goì d'oudè éxo philtron [...] (v. 537-40) 
MEN. Por que cair em meus joelhos? Uma rocha marinha ou uma onda, eis a quem imploram tuas preces. É para os meus que vai minha ajuda; a ti nenhuma afeição me toca.

\section{Pirro e Agamêmnon; Peleu e Menelau}

No primeiro episódio de As troianas de Sêneca, na segunda cena, em que Pirro e Agamêmnon debatem sobre a morte de Políxena, que é o outro tema, não ligado diretamente a Andrômaca, há no entanto certas semelhanças que não se podem deixar de notar, ao ler as duas peças trágicas: a cena da discussão entre Peleu e Menelau na Andrômaca, recordando-se ainda que essa cena não aparece em nenhuma das duas peças indicadas como fontes primárias, inclusive Pirro é apenas mencionado por Ulisses como executor de Políxena em Hécuba, e em As troianas é mencionado como o senhor de Andrômaca no sorteio das cativas.

Na Andrômaca há a cena de Peleu e Menelau, no terceiro episódio (220 versos: v. 545-765), a cena de Pirro e Agamêmnon em Sêneca (267 versos: v. 203 470). Ambas são cenas com mais de 200 versos. Embora em As troianas de Sêneca essa cena não faça parte do drama particular de Andrômaca, de qualquer maneira, dos dois personagens, Pirro será o seu senhor e pai do seu filho, pelo qual haverá a discussão de Peleu, avô de Pirro, e Menelau, que é irmão de Agamêmnon.

Em ambas as cenas as mesmas famílias entram em conflito na discussão: ou seja, a de Aquiles e a dos Atridas.

No estudo da cena de As troianas, tentar-se-á distinguir as passagens que podem ter sido influenciadas pela Andrômaca de Eurípides.

O debate das duas peças contém características semelhantes na argumentação. É interessante notar que Sêneca usa, nessa cena, muitas sentenças filosóficas, não raras em suas tragédias, e que Eurípides também usa seus conhecimentos da sofística de sua época, também não raros em suas tragédias.

Os elementos filosóficos estão presentes em todas as tragédias de Sêneca. Poderia se justificar tal característica por Sêneca ter sido um dos grandes divulgadores da filosofia estóica, em Roma. No entanto se encontram elementos filosóficos na tragédia grega em geral, e especialmente na de Eurípides, que é o modelo favorito de Sêneca (Cardoso, 1976, p. 237).

Cardoso, citando Jacqueline Duchemin, diz que não se pode considerar como a demonstração de uma atitude filosófica do poeta as afirmações contidas em sua 
obra, pois, enquanto o filósofo, para os gregos, era o homem que busca o conhecimento, opondo-se ao sofista que era o profissional da sophía, o poeta em vez de preocupar-se com a investigação e a especulação filosófica, apenas assimila e vulgariza uma doutrina já pronta (Cardoso, 1976, p. 237). É o caso de Eurípides que divulgou as tendências sofísticas de sua época. Em Sêneca, em geral, a visão metafísica seguida é de linha estóica.

A discussão em ambas as peças é pela vida de uma cativa troiana: numa, Políxena e na outra, Andrômaca. Em As troianas, Agamêmnon, no início, aparece como um sábio, pela moderação na fala, utilizando sentenças filosóficas para demonstrar a fragilidade do poder e o dever que os vencedores têm para com os vencidos, defendendo, desse modo, a tese de que não deviam sacrificar Políxena a Aquiles. Mas Pirro, que, de qualquer maneira, quer honrar o pai morto, utiliza os argumentos de que no passado Agamêmnon não hesitou em sacrificar a própria filha, Ifigênia, para partir para Tróia e trazer de lá Helena. E no decorrer do debate, os insultos pessoais se acirram, e o rei, que no início parecia um sábio, assume o mesmo nível de Pirro. Então acaba por deixar a decisão para Calcas, o adivinho, que emitirá a vontade dos deuses. Agamêmnon parece a própria figura da fragilidade do poder de que ele mesmo fala.

PYR. [...] Placida nunc subito probas

Priamique natam Pelei gnato ferum

mactare credis? At tuam gnatam parens

Helenae immolasti [...] (v. 246-9)

PYR. [...] Desaprovas, agora, subitamente, estes desejos e julgas que é cruel imolar a filha de Príamo ao filho de Peleu? Mas a tua filha, ó pai, imolaste-a a Helena [...];

PYR. Solusne totiens spolia de nobis feres?

Hac dextra Achilli uictimam reddam suam.

quam si negas retinesque, maiorem dabo

dignamque quam det Pyrrhus; et nimium diu

a caede nostra regia cessat manus

paremque poscit Priamus (v. 305-10)

PIR. Carregarás sozinho, tantas vezes, o espólio de todos nós? Com esta mão eu oferecerei a Aquiles a sua vítima. Se a negas e a reténs, oferecer-lhe-ei uma maior e digna de que Pirro a ofereça. Há muito 
tempo já que minha mão se abstém de uma morte real. Príamo exige um par;

PYR. [...] Priamus tamen

praesens rogauit; $t u$ graui pauidus metu

nec ad rogandum fortis, Aiaci preces

Ithacoque mandas clausus atque hostem tremens (v. 314-7)

PIR. Príamo, todavia, suplicou, estando pessoalmente presente; tu, aterrorizado por um grande medo e não (te sentindo) corajoso para pedir, (lhe) enviaste as súplicas de Ájax e do Ítaco, (enquanto ficavas) protegido e tremendo de medo do inimigo;

AGA. At non timebat tunc tuus, fateor, parens, interque caedes Graeciae atque ustas rates segnis iacebat belli et armorum immemor, leui canoram uerberans plectro chelyn (v. 318-21)

AGA. Teu pai, porém, nessa ocasião, não tinha medo, eu concordo, e no meio da hecatombe da Grécia e dos navios queimados, estendiase, indolente, esquecido da guerra e dos exércitos, tocando com o delicado plectro a cítara harmoniosa.

O insulto torna-se mais mordaz em 339:

AGA. Hos Scyros animos? PYR. Scelere quae fratrum caret

AGA. É Ciros que te confere esta animosidade? PIR. (Ciros) não tem irmãos (unidos) pelo crime!

Continua até o verso 347 aproximadamente, depois vem a saída de Agamêmnon:

AGA. Compescere equidem uerba et audacem malo poteram domare; sed meus captis quoque scit parcere ensis. Potius interpres deum Calchas uocetur: fata si poscent, dabo (v. 349-52)

AGA. Na realidade, eu poderia reprimir tuas palavras e dominar tua audácia com um castigo, mas minha espada sabe perdoar até mesmo 
aos cativos. Que seja, antes chamado Calcas, o intérprete dos deuses; se os destinos exigirem, eu cederei.

Em Andrômaca, vê-se Peleu defendendo a cativa, enquanto Menelau quer matá-la e também ao filho dela, dizendo estar defendendo sua filha, Hermíone, que foi lesada no leito conjugal, e isto, segundo ele, é o que há de pior para uma mulher. Menelau acusa Peleu de defender uma bárbara e se opor à esposa legítima de seu neto, Pirro.

PEL. Pròs toîsde d'eis adelphòn ồ'ephýbrisas, spháxai

kaleúsas thygatér'euethéstata

hoútos édeisas mè ou kakèn dámart'ékhes (v. 624-6)

PEL. Qual ultraje tu fizeste ao teu irmão ao pedir-lhe para sacrificar sua filha tão simplesmente, tanto que tu temias perder uma esposa culpável;

MEN. Heléne d'emókhthes'oukh hekoûs'all'ek theôn,

kaì toûto pleîston ophélesen Helláda;

hóplon gàr óntes kaì mákhes aístores

ébesan es tandrềon; he d'homilia

pánton brotoîsi gígnetai didáskalos.

Ei d'es prósopsin tês emês elthòn egó

gynaikòs éskhon mè ktaneîn, esophrónoun.

Oud' àn sè Phôkon éthelon kataktaneîn (v. 680-7)

MEN. Helena foi infeliz, não por sua vontade, mas pela vontade dos deuses, e ela fez assim o maior bem aos gregos. As armas e a guerra eram ignoradas deles: eles se formaram pela virilidade; o exercício é, em tudo, o mestre dos mortais. Se à vista de minha mulher, eu me retive de matá-la, agi sabiamente. Eu não queria ter-te visto matando Foco;

PEL. Hótan tropaîa polemíon stése stratós, ou tôn ponoúnton toúrgon hegoôntai tóde, all'ho strategòs tèn dókesin árnytai (v. 694-6)

PEL. Quando troféus inimigos são erguidos por um exército, não é para estes que sofrem que se atribui a obra: o general leva a glória deste; 
PEL. Deíxo d'egó soi mè tòn Idaîon Párin

hésso nomizein Peléos ekhthrón pote,

ei mè phtherêi têsd'hos tákhist'apò stéges

kaì paîs áteknos, hén hód'éx hemôn gegós

elâi di'oíkon ténd'epispásas kómes (v. 706-10)

PEL. Mas eu te ensinarei a ver em Páris, o homem do Ida, e em Peleu adversários do mesmo talhe, se tu não desapareceres deste teto o mais rápido, com tua filha estéril, que este filho do meu sangue arrastará pelos cabelos através da casa.

Saída repentina de Menelau no verso 729:

MEN. Ágan pronopès es tò loidoreî phérêi;

egò dè pròs bían mèn es Phthían molón

oút'oûn ti dráso phaûron oúte peísomai

kaì nûn mén - ou gàr áphthonon skholèn ékho .

ápeim'es oíkous esti gár tis ou próso

Spártes pólis tis, hé prò tôu mèn ên phile,

nûn d'ekhthrà poieî ténd'epexeltheîn thélo

stratelatégas khypokheirion labeîn (v. 729-36)

MEN. Tu te deixas muito facilmente levar para o insulto. Eu, é por força que venho a Ftia; não quero nem fazer nem sofrer nenhum aborrecimento. Agora, porque meu tempo está contado, eu volto para casa. Há, não muito longe de Esparta, certa cidade, antes nossa amiga, de que hoje os atos são hostis. Eu quero marchar contra ela à frente de minhas tropas e submetê-la.

\section{Conclusão}

Pela análise comparativa das duas obras estudadas, nota-se que Sêneca realmente se utilizou de Andrômaca como uma fonte fundamental de sua peça As troianas, que traz a personagem Andrômaca como uma figura de mãe, juntamente com Hécuba, mais desenvolvida nas peças de Eurípides, consideradas como fontes principais de Sêneca.

A tal conclusão se chega pela observaação do fato de que Eurípides é a principal fonte das peças de Sêneca, e, já que o tragediógrafo grego tem uma peça 
dedicada à personagem em questão, ou seja, a Andrômaca, além do fato de que as duas cenas estudadas em As troianas de Sêneca, que não fazem parte de As troianas ou de Hécuba de Eurípides, serem perfeitamente assimiladas às contidas em Andrômaca.

É mais interessante o estudo comparativo das obras de Sêneca com as dos tragediógrafos gregos, à medida em que se vai percebendo quais foram os objetivos que moveram Sêneca à imitação de tais peças. Pelo que se pôde ver, os trágicos latinos imitavam os gregos, mas tinham que adaptá-los aos romanos, para que a mensagem trágica fosse transmitida integralmente; também foi observada a seleção das obras gregas feita por Sêneca, na elaboração de suas peças, tendo em vista os temas que dessem margem a estudos psicológicos mais aprofundados, e ainda ao aspecto da força do crime trágico, assimilando-o ao scelus nefas romano. É também notável a preferência do trágico romano pelas obras de Eurípides, que, pelo que foi visto, se assemelha mais ao seu estilo, principalmente por exprimir mais idéias filosóficas em seu teatro.

Por tudo que foi observado, o que se conclui de mais importante é que a imitação no teatro de Sêneca não se reduz à mera cópia dos gregos, mas trata-se de um teatro de elaboração aprofundada no estudo de temas gregos renascidos na cultura romana.

\section{Notas}

* Professora de Língua Grega do Curso de Letras da Universidade Federal do Ceará e Mestre em grego pelo programa de Pós-Graduação em Letras Clássicas da FFLCHUSP.

1 Em Sêneca, Pirro, mas em Eurípides, Neoptólemo. Adotaremos a partir de agora o nome Pirro apenas, que é o adotado pela obra estudada: As troianas de Sêneca.

2 Esses níveis são apontados em Herrmann (Herrmann, 1924, p. 267-73).

3 A tradução das passagens de As troianas de Sêneca é de Zélia de Almeida Cardoso (Cardoso, 1976).

\section{REFERÊNCIAS BibLIOGRÁFICAS}

ARISTÓTELES. Poética. In: -. Ética a Nicômaco; Poética. Seleção de textos de José Américo Motta Pessanha. São Paulo: Nova Cultural, 1987. 
CARDOSO, Z. L. V. A. A construção de As Troianas de Sêneca. Tese de Doutoramento apresentada ao DLCV da FFLCH-USP. São Paulo, 1976.

DUPONT, F. Le théâtre latin. Paris: Armand Colin,1988.

EURIPIDE. Andromaque. In: -. Tragédies. Texte traduit par Louis Méridier. Paris: "Les Belles Lettres", 1927. t. 2.

EURÍPIDES. As troianas. In: -. Medéia. Hipólito. As Troianas. Tradução do grego, introdução e notas de Mário da Gama Kury. Rio de Janeiro: Jorge Zahar Ed., 1991.

-. Hécuba. In: ÉSQUILO. Os Persas; SÓFOCLES. Electra; EURÍPIDES. Hécuba. Tradução do grego, introdução e notas de Mário da Gama Kury. Rio de Janeiro: Jorge Zahar Ed., 1992.

LESKY, A. História de la literatura griega. Versión española de José Maria Díaz Regañon y Beatriz Romero. Madrid: Editorial Gredos, 1968.

HERRMANN, L. Le théâtre de Sénèque. Paris: "Les Belles Lettres", 1924.

SENECA. Troades. In: . Hércules Furens. Troades. Phoenissae. Iteratis curis edidit Humbertus Moricca. Madrid: Consejo Superior de Investigaciones Científicas, 1949.

VIRGÍLIO. Eneida. Tradução direta do latim, notas, argumento analítico e excurso biográfico por Tassilo Orpheu Spalding. São Paulo: Cultrix, s/d.

POMPEU, Ana Maria César. L’Andromaque de Euripide comme source de Les Troyennes de Sénèque.

RÉSUMÉ: On remarque une considérable influence d'Andromaque dans Les Troyennes de Sénèque, spécifiquement dans le deuxième épisode, dont la figure centrale c'est Andromaque, et dans la deuxième scène du premier épisode qui correspond au débat d'Agamemnon et de Pyrrhus sur la mort de Polyxìne.

MOTS-CLÉS: Théâtre; Sénèque; Andromaque; Les Troyennes. 